ARTICLES

\title{
Deliberation and Emancipation: Some Critical Remarks*
}

\section{Philip Yaure}

This article draws on the antebellum political thought of Black abolitionists Frederick Douglass and Martin Delany in critically assessing the efficacy of reasonableness in advancing the aims of emancipatory politics in political discourse. I argue, through a reading of Douglass and Delany, that comporting oneself reasonably in the face of oppressive ideology can be counterproductive, if one's aim is to undermine such ideology and the institutions it supports. Douglass and Delany, I argue, also provide us with a framework for evaluating alternative discursive strategies we might wish to employ in light of the limited value of reasonableness for emancipatory politics.

If [political] participation means voting, and it means compromise, and organizing and advocacy, it also means listening to those who don't agree with you. ... If you disagree with somebody, bring them in and ask them tough questions. Hold their feet to the fire. Make them defend their positions. If somebody has got a bad or offensive idea, prove it wrong. Engage it. Debate it. ... Go at them if they're not making any sense. Use your logic and reason and words. (Barack Obama, Rutgers Commencement Address) ${ }^{1}$

* I would like to thank Borhane Billi Hamelin, César Cabezas, Kimberlé Crenshaw, Manuel Käppler, Frederick Neuhouser, Dasha Polzik, Damion Scott, Alexander Rigas, Carol Rovane, and Olúfẹmi Táíwò for helpful comments and conversations at various stages of this project. The comments of two anonymous reviewers, the editors at Ethics, and my seemingly tireless interlocutors-Robert Gooding-Williams, John Colin Bradley, and Yarran Hominhhave been invaluable.

1. Barack Obama, "Remarks by the President at Commencement Address at Rutgers, the State University of New Jersey," May 15, 2016, https://obamawhitehouse.archives.gov /the-press-office/2016/05/15/remarks-president-commencement-address-rutgers-state -university-new.

Ethics 129 (October 2018): 8-38

(C) 2018 by The University of Chicago. All rights reserved. 0014-1704/2018/12901-0002\$10.00 
Fear of Muslims is RATIONAL ... the truth fears no questions. (Michael Flynn, February 26, 2016, Tweet) ${ }^{2}$

\section{INTRODUCTION}

In this article, I aim to articulate some lines of argument, present in the antebellum political writings of Frederick Douglass and his fellow Black abolitionist Martin Delany, for the claim that participation in reasonable political deliberation can be counterproductive for those seeking to advance the aims of emancipatory politics (i.e., politics that seeks to erode or eliminate various forms of oppression). I take the target of this claim to be exemplified in President Obama's exhortation to use our "logic, reason, and words" in attempting to advance our political aims through reasonable political discourse.

The norm of reasonableness in political discourse seeks to secure the provision of equal respect to the perspectives of relevant parties in deliberation. ${ }^{3}$ Reasonable political agents provide justifications for their stances which they can expect their interlocutors to endorse, and they address their interlocutors' stances by critically engaging the justifications which their interlocutors put forth. Thus, for instance, a reasonable interlocutor might address Flynn with evidence (statistical or anecdotal) and arguments to demonstrate the falsity (and indeed absurdity) of his claim. ${ }^{4}$ Emancipation is, in part, a matter of enlightenment.

Douglass, I claim, in his July 5, 1852, speech, "The Meaning of July Fourth for the Negro" (often referred to as the "Fifth of July" speech), rejects this sort of strategy for emancipatory politics in political discourse. Before a predominately white Republican audience, Douglass declares, "Where all is plain there is nothing to be argued. .. . The manhood of the slave is conceded." 5 Throughout the speech, Douglass insists that he will not argue that slavery is wrong:

Would you have me argue that man is entitled to liberty? That he is the rightful owner of his own body? You have already declared it. Must

2. Michael Flynn, "Fear of Muslims Is RATIONAL: Please Forward This to Others: The Truth Fears No Questions ... http:/ /Youtu.be/tJnW8HRHLLw," microblog, @genflynn, February 26, 2016, https:/ / twitter.com/genflynn/status/703387702998278144.

3. John Rawls, Political Liberalism (New York: Columbia University Press, 2005), 49; Iris Marion Young, Inclusion and Democracy (Oxford: Oxford University Press, 2000), 24-25; Jason Stanley, How Propaganda Works (Princeton, NJ: Princeton University Press, 2015), 94.

4. The aim of a reasonable political agent need not be to persuade her immediate interlocutor - this, for instance, seems to be neither a prudent nor a plausible aim in holding Flynn's feet to the fire. Rather, in many instances, we can understand a reasonable political agent as seeking to persuade a wider public audience by critically engaging with the justifications her interlocutors offer for their views.

5. Frederick Douglass, "The Meaning of July Fourth for the Negro," in Frederick Douglass: Selected Speeches and Writings (Chicago: Lawrence Hill, 1999), 188-206, 195. 
I argue the wrongfulness of slavery? Is that a question for Republicans? Is it to be settled by the rules of logic and argument, as a matter beset with great difficulty, involving a doubtful application of the principle of justice, hard to be understood? How should I look to-day, in the presence of Americans, dividing, subdividing a discourse, to show that men have a natural right to freedom? Speaking of it relatively and positively, negatively and affirmatively. To do so, would be to make myself ridiculous, and to offer an insult to your understanding.- - There is not a man beneath the canopy of heaven that does not know that slavery is wrong for him. ${ }^{6}$

I think that we should take Douglass's refusal to argue as a major strand of his antebellum political thought. ${ }^{7}$ Appeals to reasonableness in antebellum US political discourse, Douglass and Delany think, enable political actors invested in the maintenance of a white supremacist system of racialized slavery to manipulate deliberation in their interests. Such political actors do this in two ways. First, they frame claims about the boundaries of moral community as "open questions" in need of determination by inquiry, and they fix the outcomes of such inquiry through the exercise of domination over those they aim to exclude. Second, these political actors undermine the standing of Black political actors by maintaining that the latter's standing is dependent on the boundaries of the moral community, so that granting a Black political actor standing in deliberation over these boundaries would amount to begging the question — a result that contributes to the reproduction of racist hierarchies even in antebellum abolitionist organizations. Participation in reasonable deliberation can be counterproductive for emancipatory politics, because the norm of reasonableness is implicated in the maintenance and reproduction of social hierarchies and patterns of oppression. ${ }^{8}$

6. Ibid., 196.

7. Ultimately, for reasons of space and interpretive commitment, I don't wish to claim that this is the only position on deliberation that Douglass endorses in the decade leading up to the Civil War. My more limited claim is that this is one strategy that Douglass experiments with during this period and, more importantly, that it is one plausible (perhaps compelling) option for emancipatory politics today.

8. The critique of reasonableness presented here is one synthesized from certain moments in the antebellum political writings of Douglass and Delany. To do this properly, we have to get the details right - we have to get at what Douglass and Delany said in the pages cited below. But the unity of these details is not the result of an intention by Douglass and Delany to offer "The Douglass-Delany Critique of Reasonableness." Rather, the unity is generated ultimately by interests animating the emancipatory politics of our own moment. It is important to recognize that these interests are distant from, but by no means alien to, those animating the emancipatory politics of Black antebellum abolitionists. The critique reconstructed here is for us, but if successfully so, it is one that Douglass and Delany could by and large endorse as their own. Ultimately, the aim of this article is to help loosen the grip that certain political commitments have on us by showing that some people engaged in politics distant from, but not alien to, ours have had reason to reject them, and that such commitments are thus options 
Contemporary Western political theory is not unacquainted with projects of this form. ${ }^{9}$ For example, Lynn Sanders, in "Against Deliberation," suggests that "deliberation should not necessarily and automatically appeal to democratic theorists" because "appealing to deliberation, or taking it for granted as an appropriate democratic standard, may have a destructive effect." ${ }^{10}$ According to Sanders, the appearance of genuine deliberation can deceive us into "mistakenly decid[ing] that conditions of mutual respect have been achieved by deliberators." ${ }^{11}$ Genuine instances of deliberation (under which conditions of mutual respect have been achieved) abide by the norm of reasonableness, so when we encounter an apparent instance of deliberation, we're inclined to think that the parties to deliberation treat one another as reasonable, affording equal respect to each other's perspectives. But the appearance of reasonable deliberation is compatible with unreasonableness - with the failure by one party to accord equal respect to the perspective of another. The norm of reasonableness can give cover to forces of marginalization in a polity.

My aim in this article, however, is to present a critique which implicates reasonableness directly in the maintenance of marginalization. Sanders approaches this critique when she observes that, when confronted with prejudice in the political sphere, "sometimes, giving reasons isn't anything like the right project and suggesting that the disregarded argue against prejudice or discrimination is offensive in and of itself." ${ }^{2}$ Indeed, Sanders cites Douglass's Fifth of July speech in this connection. But Douglass and Delany, I claim, think that the imperative to give reasons not only is offensive but also can compromise the aims of emancipatory politics in circumstances of oppression.

In Section II, I situate the relevant conception of reasonableness in the context of liberal political theory. In Section III, I draw on Douglass's and Delany's antebellum political writings in order to identify a critique of this conception of reasonableness and its role in political deliberation. In Section IV, I show how Douglass and Delany diverge in their responses to

among others. See Robert Gooding-Williams, "History of African American Political Thought and Antiracist Critical Theory," in The Oxford Handbook of Philosophy and Race, ed. Naomi Zack (Oxford: Oxford University Press, 2017), 235-45; Robert Gooding-Williams, In the Shadow of Du Bois: Afro-Modern Political Thought in America (Cambridge, MA: Harvard University Press, 2009); Paul C. Taylor, "Bare Ontology and Social Death," Philosophical Papers 42 (2013): 369-89.

9. Young, Inclusion and Democracy, esp. 36-50; Joshua Cohen and Joel Rogers, "Power and Reason," in Deepening Democracy: Institutional Innovations in Empowered Participatory Governance, ed. Archon Fung (New York: Verso, 2003), 237-58; James Johnson, "Arguing for Deliberation: Some Skeptical Considerations," in Deliberative Democracy, ed. Jon Elster (Cambridge: Cambridge University Press, 1998), 161-84.

10. Lynn Sanders, "Against Deliberation,” Political Theory 25 (1997): 347-76, 348.

11. Ibid., 349 .

12. Ibid., 354 . 
their shared critique: while Douglass thinks that one can advance antislavery politics in antebellum US political discourse by declaring one's membership in the moral community, Delany thinks that, in a system of deliberation directed toward the maintenance of racialized slavery and white supremacy, such declarations cannot be heard but as premises respectful of the norm of reasonableness.

\section{REASONABLENESS AND THE AIMS OF EMANCIPATORY POLITICS}

The conception of reasonableness at issue in this article takes reasonableness as a virtue of political discourse not only in substantially just societies but also in substantially unjust societies. ${ }^{13}$ On this conception of reasonableness, where we encounter, for instance, an assertion of white supremacist ideology, "that this government was . . made by white men, for the benefit of white men and their posterity forever, and never should be administered by any except white men" and that thus "a negro ought not to be a citizen," we ought to take the stage in opposition and marshal arguments in response - as, for instance, Lincoln does in response to Stephen Douglas. ${ }^{14}$

Yet we should note that contemporary liberal political theorists do not generally hold that we have a duty to respond to the white supremacist in a reasonable manner. Gutmann and Thompson state clearly that "citizens do not have any obligations of mutual respect toward their opponents" who advocate, for example, for policies of racial or gender discrimination, because such policies violate considerations of basic liberty and opportunity, which constrain reasonableness. ${ }^{15}$ In particular, opportunity to participate in the deliberative process is typically taken to impose a substantial constraint on reasonableness. For instance, Rawls holds that reasonableness is constrained by the criterion of reciprocity, which "requires that when ... terms are proposed as the most reasonable terms of fair cooperation, those proposing them must also think it at least reasonable for others to accept them, as free and equal citizens, and not as dominated or manipulated, or under the pressure of an inferior political or social position." ${ }^{16}$ Where persons are compelled to accept terms under conditions of substantial oppression, they are deprived of the opportunity to participate

13. I would especially like to thank two anonymous reviewers for comments that greatly helped to clarify this section and the conception of reasonableness at issue in this article.

14. Abraham Lincoln, "Fourth Debate with Stephen A. Douglas at Charleston, Illinois. September 18, 1858," in The Collected Works of Abraham Lincoln, ed. Roy Basler, Marion Pratt, and Lloyd Dunlap (New Brunswick, NJ: Rutgers University Press, 1953), 3:145-201.

15. Amy Gutmann and Dennis Thompson, Democracy and Disagreement (Cambridge, MA: Belknap, 1996), 3, 17-18.

16. Rawls, Political Liberalism, 446. 
in deliberation as free and equal citizens. Moreover, where the criterion of reciprocity is breached, basic liberties are typically violated directly: "For what reasons can both satisfy the criterion of reciprocity and justify denying to some persons religious liberty, holding others as slaves, imposing a property qualification on the right to vote, or denying the right of suffrage to women?" 17 If, with many contemporary liberal theorists, we take basic liberties and opportunities to constrain the situations in which a duty to reasonableness in political discourse obtains, then we can plausibly deny that such a duty obtains in situations in which we are confronted with white supremacist views.

But the absence of a duty to engage reasonably with white supremacist ideology under conditions of substantial oppression does not itself indicate what we should do when confronted with such views under such conditions. One answer to this further question is that we in fact have a duty not to be reasonable when confronting white supremacist views under conditions of substantial oppression, because engaging in reasonable deliberation in such conditions inflicts substantial moral harm on those subjected to white supremacist ideology. Entertaining claims of inferiority with rigorous argument, even with an eye to refuting them, demeans and disrespects members of the community who are targeted by such claims. In part, this is because an implicit expression of inferiority is built into the very act of selectively entertaining claims of inferiority: members of targeted groups are implied to be inferior insofar as their claim to equality is taken as something in need of "verification," where the default assumption is that such verification is unnecessary. ${ }^{18}$ The disrespect expressed in such cases is akin to the disrespect expressed in, for example, discriminatory stop-and-frisk or airport security policies (de jure or de facto) - an expression of inferiority is built into the very act of discriminatory examination, even if one is subsequently "cleared" by the examination. ${ }^{19}$

But if the duty not to be reasonable in the face of white supremacist ideology is grounded in the disrespect constituted by expressions of inferiority, it is plausibly only pro tanto. If engaging in reasonable deliberation in the face of white supremacist ideology can plausibly erode or eliminate the conditions under which such ideology flourishes, and thus the conditions under which such disrespect arises ubiquitously, the duty not to be reasonable may be overridden. One may, for instance, seek to coun-

17. Ibid., 447.

18. We can focus on cases of selectively entertaining claims of inferiority because, in a political culture which is minimally democratic, equality is the default assumption. Any context in which a question of inferiority is posed is a deviation from this default. This does not imply that deviation in a minimally democratic political culture is infrequent.

19. This is not to say that the wrong in the latter cases is exhausted by the disrespect it expresses. 
teract discriminatory immigration policies directed (implicitly or explicitly) against Muslims by pointing to data which demonstrates that Muslims are no more likely to commit acts of violence than members of other religious groups, with an eye toward rendering the Islamophobic arguments advanced by the likes of Flynn unpersuasive to other members of the community. Insofar as "going to the data" in such circumstances qualifies as entertaining claims of inferiority-because in so doing we (perhaps implicitly) endorse a conditional like "If members of a religious group are more likely to commit acts of violence than members of other religious groups, then discriminatory security policies directed toward members of that religious group are justifiable"-it is an expression of disrespect. But such arguments might seem decisive in deliberation: we know that the data will not justify such discriminatory policies and thus will undermine Flynn's Islamophobic claims. By advancing such arguments, it appears plausible that we will erode the conditions under which such disrespect and connected harms arise. ${ }^{20}$

The matter at issue in this article concerns the conditions under which we should, in the absence of a duty of reasonableness, nevertheless comport ourselves reasonably in political discourse for the sake of advancing emancipatory political aims. The target claim is that we should comport ourselves reasonably when engaging with oppressive ideology under conditions of substantial oppression, because comporting ourselves reasonably will effectively advance emancipatory political aims. The target claim, in essence, takes a stance on the conditions in which emancipatory political actors should deem it prudent to act in accord with the norm of reasonableness.

I take the target claim to be a common (although by no means universal) feature of progressive political culture in the United States. Obama's remarks quoted above in his Rutgers Commencement Address are directed at student antiracist activists who adopt a "no platform" strategy in response to expressions of white supremacist ideology on campuses. In exhorting such activists to use their reason, logic, and words, Obama implies that engaging in reasonable deliberation is a productive means for advancing antiracist political aims. Obama's remarks, moreover, exemplify a more general attitude toward antiracist and antifascist activists - on and off university campuses — which urges that those who engage in such forms of resistance must comport themselves in accordance with values of free speech and expression.

20. This is not a case of flatfooted greater good reasoning: the claim is not that, by performing acts which constitute one sort of harm, we contribute to a distinct, greater good (or avoid a distinct, greater harm). Rather, the claim is that, by performing acts which constitute a particular sort of harm, we contribute to the erosion or elimination of the same, or closely connected, sorts of harm. 
A commitment to the target claim is not new in progressive political culture in the United States. It is reflected, for instance, in the American Civil Liberties Union's defenses of permits for rallies and demonstrations held by Nazis and the Ku Klux Klan in the 1930s, which were motivated not only by an abstract commitment to the intrinsic value of free speech but also by a concrete political strategy for advancing social justice aims: "The best way to combat their propaganda is in the open where it can be fought by counter-propaganda, protest, demonstrations, picketing-and all the devices of attack which do not involve denying their rights to meet and speak." ${ }^{21}$ If we adopt an expansive conception of modes of participating in deliberation - inclusive of protest and propaganda - then the ACLU's defense of white supremacists' permits exemplifies a commitment to reasonableness, because it is supposed that this commitment will advance emancipatory political aims.

And, indeed, while the Rawlsian per se is not committed to the target claim, Rawls himself does seem to express sympathy for the view that reasonableness is effective in advancing emancipatory aims - in particular, in the context of Lincoln's debates over the legitimacy of slavery with Stephen Douglas: "Since the rejection of slavery is a clear case of securing the constitutional essential of the equal basic liberties, surely Lincoln's view was reasonable (even if not the most reasonable), while Douglas's was not. ... What could be a better example to illustrate the force of public reason in political life?"22

To the contrary, however, Frederick Douglass and Martin Delany give us strong reasons to think that comporting ourselves reasonably in the face of white supremacy cannot contribute productively to emancipatory political aims: reasonable political conduct under conditions of substantial oppression can be counterproductive. In their antebellum political writings, Douglass and Delany demonstrate that engaging in reasonable deliberation under conditions of substantive oppression cannot reliably render white supremacist claims unpersuasive to other members of the polity and, more generally, cannot contribute to the erosion of conditions of oppression. In fact, Douglass and Delany suggest, engaging in reasonable deliberation under conditions of substantive oppression is liable to reinforce such conditions.

It should be clear, at this stage, that Douglass and Delany do not provide a critique of the role of reasonable deliberation in substantially

21. Harry Ward et al., "Shall We Defend Free Speech for Nazis in America?," American Civil Liberties Union, October 1934, 3, http:/ / documents.latimes.com/aclu-asks-1934-shall -we-defend-free-speech-nazis-america/; Laura Weinrib, "The ACLU's Free Speech Stance Should Be about Social Justice, Not 'Timeless' Principles," Los Angeles Times, August 30, 2017, http://www.latimes.com/opinion/op-ed/la-oe-weinrib-aclu-speech-history-20170830 -story.html.

22. Rawls, Political Liberalism, 484. 
just societies; their arguments are compatible with the contemporary liberal theorist's commitment to reasonable deliberation in such circumstances. At issue for Douglass and Delany is the role of reasonableness in advancing from conditions of substantial oppression toward a substantially just society; in Charles Mills's sense of the term, the question is the extent to which the norm of reasonableness figures into a program of corrective justice, particularly where the aim is to erode or eliminate white supremacist ideology and institutions. ${ }^{23}$

It is also important to note that the model of deliberation which Douglass and Delany target does not assume that one's direct interlocutors must be sincere in order for the deliberation to qualify as reasonable. Sincere participants in deliberation exhibit the virtue of open-mindedness: they are open to revision of their stances as dictated by the reasons and evidence advanced in a particular deliberative context. But in order for deliberation to qualify as reasonable, we needn't assume that the immediate advocates of systems of oppression are sincere, open-minded interlocutors. Rather, we must assume that the audience - the wider public - is generally composed of sincere, open-minded interlocutors. Thus, we needn't imagine that those striving to advance emancipatory aims by means of reasonable deliberation sought to persuade Stephen Douglas (or seek to persuade Michael Flynn). We should rather understand the goal for proponents of the target claim as persuading members of the wider public to endorse and advance emancipatory aims. ${ }^{24}$ Douglass and Delany give us strong reasons to think not only that the former sort of project is futile (with which many proponents of the target claim would agree) but also that the latter sort of project, directed at persuading the public, is untenable.

\section{A CRITIQUE OF REASONABLENESS IN EMANCIPATORY POLITICS}

In the letter prefacing his 1855 autobiography, My Bondage and My Freedom, Frederick Douglass invokes the image of a court of law to characterize the political situation around American slavery: "This system [i.e., chattel slavery] is now at the bar of public opinion-not only of this country, but of the whole civilized world - for judgment. Its friends have made for it the usual plea- 'not guilty;' the case must, therefore, proceed. Any facts, either from slaves, slaveholders, or by-standers, calculated to enlighten the public mind, by revealing the true nature, character, and tendency of the slave

23. Charles W. Mills, Black Rights/White Wrongs: The Critique of Racial Liberalism (New York: Oxford University Press, 2017), esp. chaps. 8 and 9.

24. I do assume, then, that we can attribute some degree of sincerity (i.e., some degree of open-minded responsiveness to reasons) to the wider public in the relevant deliberative contexts. 
system, are in order, and can scarcely be innocently withheld." ${ }^{25}$ Douglass's invocation of a court of law suggests that the norm of reasonableness is operative in this political discourse. The legitimacy of slavery is an open question before "the bar of public opinion," awaiting judgment; those seeking to establish its "guilt," or "innocence," must "enlighten the public mind" by demonstrating the "true nature ... of the slave system."

Yet Douglass goes on to observe that the institution of slavery is not the only matter up for deliberation: "Not only is slavery on trial, but unfortunately, the enslaved people are also on trial." ${ }^{26}$ The human dignity of Black people appears as a matter for deliberative inquiry because it is implicated in the justifications slavery's advocates advance in defense of the institution: "It is alleged, that they are, naturally, inferior; that they are so low in the scale of humanity, and so utterly stupid, that they are unconscious of their wrongs, and do not apprehend their rights." ${ }^{27}$ In order to qualify as reasonable, those who invoke white supremacist ideology in defense of chattel slavery must concede such claims as open questions to be resolved through deliberation. To understand a claim as an open question is to recognize that deliberation might confirm or refute the claim. In turn, antislavery's advocates, if they are to comport themselves reasonably, must critically engage white supremacist justifications of slavery on terms that they can plausibly expect the wider public - if not slavery's advocate herself-to endorse.

It is precisely this sort of emancipatory political strategy that Douglass takes aim at in his Fifth of July speech: "But I fancy I hear some one of my audience say, it is just in this circumstance that you and your brother abolitionists fail to make a favorable impression on the public mind. Would you argue more, and denounce less, would you persuade more and rebuke less, your cause would be much more likely to succeed." ${ }^{28}$ Douglass, in this speech, maintains that "where all is plain there is nothing to be argued": "That point is conceded already. Nobody doubts it. . . The manhood of the slave is conceded." He denies that reasonableness ("argue more, denounce less") is of use to antislavery politics when confronting putative justifications for the legitimacy of slavery. It is not the "light" of "convincing argument" that is needed, but the "fire" of "scorching irony." ${ }^{29}$ The humanity of the enslaved and the wrongness of slavery are matters to be insisted, not deliberated, on; open questions about the human dignity of Black people ought to be refused.

25. Frederick Douglass, My Bondage and My Freedom (Urbana: University of Illinois Press, 1987), 4.

26. Ibid.

27. Ibid.

28. Douglass, "Meaning of July Fourth for the Negro," 195.

29. Ibid., 195-96. 
In Douglass's position that, on the issues of slavery and white supremacy, all is plain and there is nothing to be argued, we can distinguish two elements: (1) a refusal to respect the norm of reasonableness in political discourse about the (il)legitimacy of slavery and white supremacy, and (2) a declaration that Black people are members of the moral community of the US polity. In this section, we will focus on the grounds for element (1), drawing in complementary fashion on the antebellum political writings of Douglass's fellow Black abolitionist Martin Delany. In the antebellum writings of Douglass and Delany, we can identify two reasons for the refusal to engage in reasonable deliberation. First, by appeal to the norm of reasonableness, defenders of slavery and white supremacy are able to fix deliberative outcomes in their favor: where a stance on the boundaries of moral community is understood as a claim in need of justification, those invested in systems of slavery and white supremacy can exercise their power to reliably produce justifications for exclusionary boundaries of moral community - conditions of domination produce justifications for claims of inferiority. Second, where the boundaries of moral community are an open question, advocates of slavery and white supremacy can compromise the standing of those whose claim to membership is under interrogation (i.e., Black political actors) by insisting that granting Black political actors standing in such deliberations would amount to begging the question in favor of more expansive boundaries of moral community. As we will see, this is a "worry" to which even white abolitionists were responsive.

\section{A. Fixing Deliberative Outcomes}

Given the picture of antebellum political discourse that Douglass sketches in the letter prefacing My Bondage and My Freedom, we can take Douglass's refusal to engage in reasonable deliberation in the Fifth of July speech to center appeals to white supremacist ideology: Douglass refuses to refute the claim that Black people are inferior, and thus not members of the moral community, by addressing the justifications that slavery's advocate advances in defense of the claim. Douglass refuses to do so (in part) because he thinks that once the dispute is framed as a matter of competing justifications, slavery's advocates will be able to exercise the power they wield under conditions of substantial oppression to fix deliberative outcomes in their favor. As an initial motivation for Douglass's refusal, we might observe that comporting ourselves reasonably in the face of white supremacist ideology "risk [s] conferring unmerited dignity" on the "transparently bad reasons [whites] had for the way they treated blacks," by "tacitly characterizing the conflict as one in which reasonable people could disagree." ${ }^{0}$

30. Peter C. Myers, Frederick Douglass: Race and the Rebirth of American Liberalism (Lawrence: University Press of Kansas, 2008), 50; Bernard Boxill, "Douglass against the Emigrationists," in Frederick Douglass: A Critical Reader, ed. Bill Lawson and Frank Kirkland (Oxford: Blackwell, 1999), 21-49, 42. 
Yet, one may insist, if the reasons marshaled in defense of white supremacist ideology by slavery's advocate are really "transparently bad," the danger that reasonableness presents to antislavery politics must surely be minimal. Premises in general may lead any which way, but here the proper premises will surely vindicate abolition. With some patience and persistence, the right arguments will carry the day for antislavery's advocate in the deliberative sphere. (Our objector would hasten to add: this is not to say that the aims of antislavery politics are achieved once the arguments succeed-slavery's advocate would still have brute force and power to protect the institution.)

A substantial portion of Martin Delany's The Condition, Elevation, Emigration, and Destiny of the Colored People of the United States is devoted to undermining just this thought. Delany maintains that African Americans have a "natural claim upon the country — claims common to all others of our fellow citizens - natural rights, which may, by virtue of unjust laws, be obstructed, but never can be annulled." ${ }^{31}$ Delany's contrast between obstruction and annulment might seem to suggest our objector's view: once the obstructions of transparently bad reasons are cleared away, African Americans' claim to citizenship will be vindicated - indeed, there is nothing that could be offered as an adequate justification for annulling this claim.

Yet Delany goes on to contrast this natural claim with the procedure of political deliberation: "But according to the economy that regulates the policy of nations, upon which rests the basis of justifiable claims to all freemen's rights, it may be necessary to take another view of, and enquire into the political claims of colored men."32 Rights presented as political claims must, on the view with which Delany engages, be "justifiable" - they must be presented in terms that one might reasonably expect one's interlocutors to endorse.

The justification for African Americans' political claim to citizenship that Delany considers is "that each person so endowed, shall have made contributions and investments in the country." ${ }^{33}$ Since "where there is no investment there can be but little interest" in the welfare of the state, the question of "what claims then have colored men, based upon the principles set forth, as fundamentally entitled to citizenship" is to be settled by a demonstration of the contributions made by African Americans to the United States, as soldiers, businesspeople, mechanics, authors, artists,

31. Martin Delany, The Condition, Elevation, Emigration, and Destiny of the Colored People of the United States (Bensenville, IL: Lushena, 2014), 48. I switch to the term "African American" here to reflect the fact that Delany's natural claim argument concerns specifically those born or otherwise naturalized into the United States.

32. Ibid.

33. Ibid. 
professionals, scholars, and farmers. ${ }^{34}$ By enumerating dozens of examples of these contributions, Delany means "to refute the objections urged against us, that we are not useful members of society." ${ }^{35}$ In these hundredsome pages of Condition (nearly half the text!), then, we can understand Delany as rehearing a justification for African Americans' claim to citizenship. These pages exemplify the deliberative norm of reasonableness, as Delany seeks to refute the objections of those who deny this claim by appeal to a principle ("contribution to the nation") that he expects his interlocutors would endorse, and which he establishes by appeal to "marks and features"-historical evidence of Black people's "investment" in the United States. ${ }^{36}$ Indeed, Delany suggests that the argument he presents here must, if any argument will, vindicate African Americans' claim to citizenship: "If such evidence of industry and interest, as has been exhibited in the various chapters on the different pursuits and engagements of colored Americans, do not entitle them to equal rights and privileges in our common country, then indeed, is there nothing to justify the claims of any portion of the American people to the common inheritance of Liberty." ${ }^{37}$

But, Delany thinks, this in fact amounts to a demonstration that there is no viable possibility of furthering antislavery's political aims through reasonable deliberation. At the conclusion of his defense of African Americans' political claim to citizenship, Delany signals a shift in gears: "We proceed to another view of our condition in the United States." 38 That view takes as its point of departure the Fugitive Slave Act of 1850, which Delany reproduces in full. The act, in Delany's analysis, reduces "every colored person in the United States - save those who carry free papers of emancipation, or bills of sale from former claimants or owners - to a state of relative slavery; placing each and every one of us at the disposal of any and every white who might choose to claim us, and the caprice of any and every upstart knave bearing the title of 'Commissioner." "39 By legally codifying re-

34. Ibid., 48-50.

35. Ibid., 92.

36. Cora Diamond, in her reading of J. M. Coetzee's The Lives of Animals, encourages us to "look with some serious puzzlement at attempts to establish moral community, or to show it to be absent, through attention to "marks and features." Cora Diamond, "The Difficulty of Reality and the Difficulty of Philosophy," in Philosophy and Animal Life, ed. Stanley Cavell (New York: Columbia University Press, 2008), 43-90, 86 n. 21.

37. Delany, Condition, 145.

38. Ibid. This second reference to "another view" should recall Delany's initial shift, in chap. 6, to consideration of "another view"- the political claim defended in the intervening pages. With these parallel references to alternative views, we can understand Delany as stepping into and out of the position of the antislavery advocate who attempts to pursue her politics by comporting herself reasonably in the deliberative sphere.

39. Martin Delany, "Political Destiny of the Colored Race," in Martin R. Delany: A Documentary Reader, ed. Robert S. Levine (Chapel Hill: University of North Carolina Press, 2003), 245-79, 272. See also Delany, Condition, 154: "We are slaves in the midst of freedom waiting... 
lations of domination between whites and Blacks that are fundamentally incompatible with Black people's claim to citizenship, the act reveals that Black people's claim to citizenship has not been vindicated at the bar of public opinion. Since the facts that Delany has laid out in the prior hundred pages of Condition should, if any facts could, justify such a claim to citizenship, the implication is that no justification which appeals to facts in this way - as "marks and features" that satisfy some criterion for the boundaries of moral community - could vindicate the claim to citizenship of Black people in antebellum political discourse..$^{40}$

This echoes Douglass's thought when he asks of his audience in the Fifth of July speech, "Is it not astonishing that," given the types of contributions Delany enumerates in Condition, "we are called upon to prove that we are men?" ${ }^{41}$ From Douglass's explicit refusal to deliberate over the boundaries of moral community, and from Delany's demonstration of the inadequacy of "marks and features" justifications for the claim to citizenship, it is apparent that Douglass does not mean that such a proof is so obvious that it should be tedious to spell out. Rather, Douglass suggests that, where the claim in question should be so clearly and plainly settled, we should be suspicious of a demand for "proof."

Delany reinforces this suspicion by identifying the role that reasonableness itself plays in compromising antislavery politics responsive to the norm. At the outset of Condition, he asserts that "there have in all ages, in almost every nation, existed a nation within a nation ... deprived of equal privileges by their rulers." ${ }^{42}$ In order for such domination to be effective, the "inferiority by nature as distinct races" of the dominated must be "actually asserted" in order "to appease the opposition that might be interposed on their behalf." ${ }^{43}$ That is, natural inferiority is offered as a justification for domination in the face of objections to the legitimacy of that domination. On this picture, the dominating class is responsive to the norm of reasonableness because it is providing a justification for its stance in the face of a counterclaim.

One would think, then, that the justificatory priority between cases of arbitrary rule and assertions of natural inferiority works in this way:

for masters to come and lay claim to us, trusting to their generosity, whether or not they will own us and carry us into endless bondage."

40. This, surely, is not the only purpose of the detailed descriptions of African Americans' various contributions to the US polity in the first hundred pages of Condition. It seems plausible that one other purpose is to demonstrate the viability of Delany's emigrationist program: that Black people in the United States are already perfectly positioned to create their own polity, or contribute to another, elsewhere.

41. Douglass, "Meaning of July Fourth for the Negro," 195-96.

42. Delany, Condition, 11 .

43. Ibid., 11-12. 
claims of natural inferiority, "established" (in whatever tenuous fashion) on independent grounds, are put forward to legitimate instances of arbitrary rule. However, Delany's analysis of the Fugitive Slave Act of 1850 suggests that the relationship between arbitrary rule and assertions of natural inferiority is more sinister. According to Delany, the law enacts a "corruption of blood ... by which a person is degraded and deprived of rights common to the enfranchised citizen." ${ }^{44}$ In particular, the law renders "the colored people of the United States . . liable at any time, in any place, and under all circumstances, to be arrested - and upon the claim of any white person, without the privilege, even of making a defense, sent into endless bondage." ${ }^{55}$ The specific policy laid out in the law reinforces conditions of domination under which any Black person is subject to the arbitrary power of any white person. But in so doing, Delany maintains, the law "stamps us with inferiority - upon us has this law worked corruption of blood." ${ }^{46}$ The political condition of domination produces relations of superiority/inferiority between racialized classes of persons - the appearance of natural inferiority depends on the political domination it is supposed to justify.

But this circular relation between political domination and natural inferiority does not, in Delany's eyes, provide antislavery's advocate with a decisive point in deliberation. Rather, the interlocking character of conditions of political domination and claims of natural inferiority renders both impervious to the modes of intervention offered by reasonable deliberative politics: political domination is justified by claims of natural inferiority which are in turn justified by appeal to conditions that are themselves the product of racist political domination. Elizabeth Anderson captures this interlocking character in a postbellum context when she writes, "Segregation causes patterns of racial inequality that influence the ways racial groups represent one another. These representations, in turn, reinforce practices of segregation and reproduce categorical inequality." ${ }^{47}$ The deck is stacked against antislavery's advocate because an attempt to delegitimize racist political domination runs up against the justification of inferiority, while an attempt to refute a claim of inferiority runs up against the reality of racist political domination.

Thus, in laying out his general theory of racist political domination, Delany remarks with poignant ambiguity, "Wherever there is arbitrary rule, there must be, on the part of the dominant classes, superiority be assumed." ${ }^{48}$ The line suggests two readings. First, where a dominant class

44. Ibid., 153.

45. Ibid., 153 .

46. Ibid., 157.

47. Elizabeth Anderson, The Imperative of Integration (Princeton, NJ: Princeton University Press, 2013), 44.

48. Delany, Condition, 12. 
wields arbitrary power over another class and its members take themselves to do so legitimately, they must suppose that they are superior - assertions of inferiority justify domination. Second, where a dominant class wields arbitrary rule, its members seize a position of superiority over the dominated classes - domination yields the appearance of inferiority. I think that Delany's ambiguity here is intentional: the ambiguity captures the interlocking character of domination and claims of inferiority. The preceding lines of chapter 1 capture the domination-justified-by-inferiority direction; Delany's analysis of the Fugitive Slave Act in chapter 16 as enacting a "corruption of blood" captures the inferiority-justified-by-domination direction. It thus seems that the interests of white supremacy and slavery will carry the day, because they will exercise domination to produce the appearance of inferiority, which will justify their narrowed boundaries of moral community before the court of public opinion.

One might object to the inevitability of this picture. After all, can't advocates of emancipatory politics point out that appearances of inferiority are just so - and often pretty flimsy ones at that? And if the appearances of inferiority are the products of domination, can't we point to this fact to undermine claims of inferiority? There are still plenty of deliberative avenues available to antislavery's advocate.

Such avenues are certainly available, but this picture is a far cry from the decisive argument that unequivocally demonstrates Black people's claim to moral community. We now have to unveil particular claims of inferiority as products of particular conditions of domination. While some piecemeal engagements will be won, others will be lost. Moreover, even the victories of antislavery's advocate are rendered precarious by the command of reasonableness to follow the premises where(ever) they take us. This command forces us to countenance the idea that the right premises might take us elsewhere. An audience which allows that an argument for the rightness of slavery and white supremacy might be just offstage is not an audience that can be relied on in the face of fire. Sophistry is the cheapest weapon in the arsenal of oppressive institutions.

\section{B. Undermining Standing}

It is apparent, then, that adhering to the norm of reasonableness can compromise emancipatory politics by enabling oppressive institutions to fix deliberative outcomes through domination which produces the appearance of inferiority, and which is then appealed to in order to justify those very conditions of domination. But Douglass and Delany also maintain that reasonableness can compromise antislavery and antiracist politics by undermining the standing of Black political actors in political deliberation. In particular, they emphasize how the standing of Black political actors is undermined even in abolitionist organizations. 
Of the abolitionists' creed, Delany remarks, "It was urged, and it was true, that the colored people were susceptible of all that the whites were, and all that was required was to give them a fair opportunity, and they would prove their capacity ... that public opinion could and should be corrected upon this subject." ${ }^{99}$ But Delany observes that the result of this project of correcting public opinion through "proof" of capacity (i.e., of establishing membership in the moral community through the demonstration of the proper marks and features) is that "we find ourselves occupying the very same position in relation to our Anti-Slavery friends, as we do in relation to the pro-slavery part of the community - a mere secondary, underling position, in all our relations to them, and any thing more than this, is not a matter of course affair - it comes not by established antislavery custom or right, but like that which emanates from the proslavery portion of the community, by mere sufferance. ${ }^{50}$ Unsurprisingly, such organizations fail to achieve the emancipatory ends that they pursue: "We are ... still occupying a miserable position in the community, wherever we live." ${ }^{\prime 1}$ Here Delany links the persistence of social relations of racist domination, even in organizations dedicated to their eradication, to a conception of politics centered on proof and demonstration-a politics that is thereby responsive to the norm of reasonableness.

Douglass offers insight into the mechanics of this recapitulation of racist hierarchies in chapter 23 of My Bondage and My Freedom. Joining the ranks of William Lloyd Garrison's antislavery lecturers, Douglass finds that his audiences view him as "brand new fact," "generally introduced as a 'chattel,' - a 'thing' - a piece of southern 'property' - the chairman assuring the audience that it could speak." ${ }_{52}$ One might expect that Douglass's fellow white abolitionists would affirm Douglass's standing as a participant in public discourse on slavery. Instead, the white abolitionists opt to make use of audiences' objectification of Douglass and deploy him as a mere body of testimony, instructing Douglass to "give us the facts, [for] we will take care of the philosophy." ${ }^{53}$ Where antislavery politics respects the norm of reasonableness by seeking to correct public opinion through demonstrations of equality, Douglass's role is circumscribed to narrative.

Douglass is, for a time, reduced to a body of testimony on the antislavery lecture circuit because he is positioned to fulfill a particular role in a deliberative context in which the matter is an open question. This particular role, the furnishing of marks and features to which the arguments of

49. Ibid., 26.

50. Ibid.

51. Ibid., 28.

52. Douglass, My Bondage and My Freedom, 220.

53. Ibid. 
antislavery's white advocates will appeal, ${ }^{54}$ compromises Douglass's capacity to participate in deliberative politics, insofar as his white interlocutors treat the categories of offering narrative and doing philosophy as mutually exclusive in this context. The acceptance of one's narrative as legitimate depends on one's incapacity to philosophize: one can be either the body of testimony or the eloquent advocate, but not both.

But why would one treat narrative and argument as exclusive categories here? Arguments before the court of public opinion must be made by those who have appropriate standing to make them; in this case, those who have appropriate standing are those who are situated within the boundaries of moral community. But Douglass's claim to moral community is precisely what is being contested in deliberation over slavery, which means that his standing to advance arguments in the antebellum deliberative sphere appears, to much of his audience, uncertain. In the eyes of the white abolitionists who instruct Douglass to leave the philosophy to them, for Douglass to advance arguments against slavery would render the abolitionists vulnerable to accusations of begging the question: Douglass's arguments should be countenanced only if he has the standing to make them, but his standing is precisely the matter at issue, so his audience can't countenance Douglass's arguments until the issue has been resolved. Narrative and argument thus become exclusive categories because it is the narrative of those subjected to slavery and white supremacy that is needed to advance antislavery and antiracism in the deliberative sphere, but, if the abolitionists are going to be "reasonable" deliberators, it is only those who cannot supply the narrative (whites) who can advance the argument without being accused of begging the question. ${ }^{55}$

Not only are narrative and argument treated by the white abolitionists whom Douglass works with as exclusive categories, but narrative is also understood to be subordinate to argument. Douglass's narrative provides the raw materials which the white abolitionists' arguments organize. This hierarchical division of discursive labor lays the groundwork for a broader hierarchical division of labor in predominately white abolitionist organizations, as the white abolitionists, whose recognized standing in the community is secure, take on overarching organizational roles in these organizations. Because such organizations incorporate the same racialized hierarchies they are supposed to resist, their capacity to erode (much less eliminate!) white supremacist ideology and institutions is severely circumscribed.

54. "Intended to reorient white readers' moral compasses, the slave narrative's political effectiveness hinged on its status as empirical proof." Nolan Bennett, "To Narrate and Denounce: Frederick Douglass and the Politics of Personal Narrative," Political Theory 44 (2016): 240-64, 245 .

55. It is worth noting that the assumed opposition between narrative and argument is a point that contemporary critical race theorists have also had to resist. See, e.g., Patricia Williams, The Alchemy of Race and Rights (Cambridge, MA: Harvard University Press, 1992), 47-51. 
Douglass and Delany thus argue that reasonable deliberation is counterproductive for the aims of emancipatory politics because (1) slavery's advocate is able to exploit a connection between claims of inferiority and conditions of domination in order to systematically manipulate the judgments of the court of public opinion in her favor, and (2) worries about whether their audience will recognize the standing of Black political actors move white abolitionists to structure their discursive strategies, and organizations, in ways reflective of white supremacist ideology, severely circumscribing their efficacy. The urgent question, if comporting oneself reasonably under conditions of substantive oppression is counterproductive in this way, is how, if at all, the aims of emancipatory politics can be advanced in political discourse.

\section{DOUGLASS AND DELANY: TWO RESPONSES TO THE CRITIQUE}

In response to their shared critique of reasonable deliberation as a means for combating racist ideology and institutions, Douglass and Delany offer radically different prescriptions. For Douglass, because the norm of reasonableness is a condition of demanding change in antebellum political deliberation, the key is to short-circuit the norm where it compromises antislavery politics. Douglass presents the demand at the core of antislavery-recognition of Black people's membership in the moral communitythrough declaration, impervious to demands for further justification, without abdicating a general responsibility to reasonableness in deliberation. ${ }^{56}$ For Delany, because the norm of reasonableness is a condition of demanding change in antebellum political deliberation, antislavery cannot advance its aims in this sphere. Douglass's declarations, Delany thinks, will inevitably be heard by his audience as justifications open to further assessment and dispute. Delany maintains that the norm of reasonableness is so entrenched in the institution of antebellum political deliberation, especially as expressed in white Americans' esteem for law, that declaration cannot be understood by Douglass's audience as reflecting the logic of the institution-a viable antislavery politics thus must pursue strategies in other spheres.

\section{A. Douglass's Declarations}

Douglass's strategy in the Fifth of July speech is to seize on the mechanisms that tilt deliberation in favor of slavery's advocate and show that

56. In connection with declaration, see Bennett's discussion of denunciation and the recollection of communal attachments in Bennett, "To Narrate and Denounce." I am indebted to Kimberlé Crenshaw for emphasizing the role of declaration in this connection. 
recognition of the slave's membership in moral community is conceded in the very exercise of these mechanisms:

Must I undertake to prove that the slave is a man? That point is conceded already. Nobody doubts it. The slaveholders themselves acknowledge it in the enactments of laws for their government. They acknowledge it when they punish disobedience on the part of the slave. There are seventy-two crimes in the state of Virginia which, if committed by a black man, (no matter how ignorant he be), subject him to the punishment of death; while only two of these same crimes will subject a white man to the like punishment. What is this but the acknowledgement that the slave is a moral, intellectual, and responsible being? The manhood of the slave is conceded. It is admitted in the fact that southern statute books are covered with enactments forbidding, under severe fines and penalties, the teaching of the slave to read or write. ${ }^{57}$

The laws that Douglass refers to in this passage are part of the system of racist domination that, in Delany's words, debases Black people "beneath the level of the recognised basis of American citizenship." ${ }^{58}$ Take, for instance, antiliteracy laws: the domination exercised in inhibiting the literacy of slaves enables slavery's advocate to appeal to the apparent intellectual inferiority of the slave ("They aren't our equals; they can't read"). Indeed, such laws can distract from the plain fact that slaves can read and write - the issue can easily become that such skills were gained "illegally," rather than the plain fact to which their skills testify (as if these abilities were witnesses in a trial that had to conform to rules of evidence). Similarly, a regime of racist criminal laws and the severe punishments that accompany it can give the appearance, to a white audience with the right interests, that there is something from which they need protecting. Blackness is asserted as inferior because it bears the marks of criminality, through laws which are in fact constitutive of the system of domination to which Black people are subjected-what Delany calls "corruption of blood." 59

Douglass, in the passage above, turns all this on its head. Contrary to the reasonable antislavery advocate, who will insist that Black people meet the criterion of moral community in spite of the apparent marks and features produced by corruption of blood, Douglass maintains that antislavery's point is conceded in the laws themselves, and that there is thus

57. Douglass, "Meaning of July Fourth for the Negro," 195.

58. Delany, Condition, 153.

59. Robert Gooding-Williams, "Ideology, Social Practices, Anti-black Concepts" (unpublished manuscript). 
no need to argue that "the slave is a man" through any appeal to "true" marks and features. In preventing people from learning to read and write, one necessarily acknowledges their capacity to read and write; in subjecting people to punishment for the violation of laws, one necessarily acknowledges their capacity to bear moral responsibility. The aim of these practices may be dehumanization, but one can only attempt to dehumanize one's fellow human beings. Such laws, implicated in the corruption of blood that undermines the standard "reasonable" antislavery strategy, thus themselves concede antislavery's stance on the boundaries of moral community.

Slavery's advocate, of course, can object to the characterization of antiliteracy laws as "preventing" the exercise of a capacity in this way, or reject a conception of punishment that implicates moral agency in this way. That is to say, she can object to the justification that Douglass supplies for his claim that "the manhood of the slave is conceded." It then seems that, in order to conform to the norm of reasonableness, Douglass must supply further argument to defend his characterization of antebellum law as inhibiting and punishing slaves in a way that concedes their membership in moral community. Such a defense would involve asserting that slaves have capacities which are being inhibited and agency which warrants punishment-but then the whole thing seems to come down to marks and features again.

Instead, Douglass plainly declares that "it is enough to affirm the equal manhood of the Negro race." ${ }^{60}$ While he gestures to an appeal to marks and features relevant to moral community by enumerating a list of practices, from planting to writing to thinking to worshiping, in which Black people undeniably engage, he maintains that "the time for such argument has passed." ${ }^{61}$ Instead, in the realm of political discourse, antislavery advocates should rely on the fact that "there is not a man beneath the canopy of heaven that does not know that slavery is wrong for him." 62

That every person sees that slavery is wrong for her, and that every person thus sees that she is a member of the moral community, suggests to Douglass that those in the court of public opinion "have a sense of justice, though they may not consult it often and appropriately." ${ }^{33}$ This grounds, for Douglass, a discursive strategy which aims at the recovery of moral common sense. Douglass often appeals to common sense in order to ground his political critiques, particularly in the context of law. Of Scott v. Sanford, he remarks, "We can appeal from this hell-black judgment of the Supreme Court, to the court of common sense and common hu-

60. Douglass, "Meaning of July Fourth for the Negro," 195-96.

61. Ibid., 196 .

62. Ibid.

63. Boxill, "Douglass against the Emigrationists," 41-42. 
manity." ${ }^{64}$ And in advocating for an antislavery reading of the US Constitution, Douglass maintains that "the constitutionality of slavery can be made out only by disregarding the plain and common-sense reading of the Constitution." ${ }^{\prime 5}$ These appeals to common sense are meant to combat what Douglass calls the "moral blindness of the American people." ${ }^{\prime 6}$ Douglass's reference to "moral blindness" suggests that what is at issue is a matter of insensitivity on the part of his audience; the shape of the intervention involves making his audience sensitive to something already present to them. ${ }^{67}$ Two characteristics of common sense make it a strong candidate for grounding a transition from insensitivity to sensitivity. First, we can understand common sense as "insurgent," persisting in the absence of recognition by Douglass's audience ${ }^{68}$ Second, we can understand common sense as "the domain of simple, quotidian determinations and basic moral precepts, of truths that should be self-evident to all," and thus plainly accessible to Douglass's audience. ${ }^{69}$

As a matter of common sense, one is brought to "see the plain moral truth" that antiliteracy laws inhibit the capacities of slaves and that laws with severe punishments ascribe moral agency to those subjected to them. ${ }^{70}$ This contrasts with the mode of deliberative inquiry, on which Douglass would inquire after what the law says and its empirical effects, determine through this inquiry that the law inhibits capacities, and then infer that those who are being inhibited by the law are members of the moral community because the capacities which the law inhibits fall under the criterion of membership in moral community. Instead, if acknowledging that antiliteracy laws inhibit capacities and that Black people are members of the moral community is a matter of moral common sense, one comes to such acknowledgment all at once. In order to understand antiliteracy laws as inhibiting the capacities of slaves, one must already recognize slaves as members of the moral community, and the recognition of slaves as members of the moral community is itself achieved through recognizing, for instance, antiliteracy laws as inhibiting the capacities of slaves. The idiom of "coming to see" (or "cultivating sensitivity") contrasts with a process of piecewise inference. Whereas the latter is a matter of coming to discover

64. Frederick Douglass, "The Dred Scott Decision," in The Life and Writings of Frederick Douglass, ed. Philip S. Foner and Yuval Taylor (New York: International, 1950), 2:407-25, 411-12.

65. Frederick Douglass, "The Constitution of the United States: Is It Pro-Slavery or AntiSlavery?," in The Life and Writings of Frederick Douglass, ed. Philip S. Foner and Yuval Taylor (New York: International, 1950), 2:467-80, 477.

66. Douglass, "Dred Scott Decision," 416.

67. José Medina, The Epistemology of Resistance (Oxford: Oxford University Press, 2012).

68. David Graeber, Direct Action: An Ethnography (Oakland, CA: AK, 2009), 213.

69. Sophia Rosenfeld, Common Sense: A Political History (Cambridge, MA: Harvard University Press, 2011), 3.

70. Boxill, "Douglass against the Emigrationists," 42. 
further things, the former is a matter of coming to acknowledge something already present. Acknowledgment here involves a shift in attitude in which one becomes sensitive to antiliteracy laws as inhibiting, rather than a shift in which one discovers that antiliteracy laws turn out to be the sort of things that inhibit capacities of those subject to them, as if this were some further fact about antiliteracy laws which one could intelligibly deny while still having a grip on what antiliteracy laws are and how one goes about enforcing them. The failure here is not rectified by supplying further facts; rather, it is rectified by bringing one to see things as they already are. ${ }^{71}$

According to Boxill, Douglass catalyzes this recovery of moral common sense through a project of moral suasion:

Sometimes, with our connivance, our feelings enable us to ignore that we are acting for transparently bad reasons. Moral suasion involves techniques for manipulating these feelings and consequently for redirecting our attention to the obvious errors that we contrive not to see. Such techniques include eloquence, sarcasm, wit, mockery, and mimicry, and in the pacific part of his career as orator and abolitionist Douglass used them all to try to embarrass and shame his audiences and to manipulate their feelings to make them see the plain moral truths that their pride and greed and vanity had enabled them to ignore. ${ }^{72}$

I would add that, in light of Douglass's critique of reasonableness, it is not just matters of "feeling" that are understood to interfere in recognition of plain moral truths, but also matters of reason. ("We need to figure out if those people satisfy these criteria.") Moral suasion is thus not an intervention against irrational ("emotional") interference with rational processes by arational means (eloquence, sarcasm, wit, etc.), but rather a project of clearing away everything - be it a matter of feeling or reason-that prevents one from acknowledging plain moral truth.

The mechanism of moral suasion is especially vivid when we consider the Fifth of July speech as Douglass's declaration of his own membership in moral community before his predominately white (and predominately antislavery) audience. At the podium Douglass enacts eloquence, sarcasm,

71. Jonathan Havercroft and David Owen, "Soul-Blindness, Police Orders and Black Lives Matter: Wittgenstein, Cavell, and Rancière," Political Theory 44 (2016): 739-63, esp. 741-45. The distinction between knowing and acknowledging made here draws on Cavell: see Stanley Cavell, "Knowing and Acknowledging," in Must We Mean What We Say? (Cambridge: Cambridge University Press), 238-66; and "Between Acknowledgment and Avoidance," in The Claim of Reason (Oxford: Oxford University Press, 1999), 329-496. See also the discussion of "innate democratic dignity" as a "right to be seen" in Nick Bromell, "Democratic Indignation: Black American Thought and the Politics of Dignity," Political Theory 41 (2013): 285-311, 302.

72. Boxill, "Douglass against the Emigrationists," 42. 
wit, mockery, mimicry, and, indeed at times, reasonableness; he brings his audience to feel (one must imagine) embarrassment and shame; he stands before his audience as a member of the moral community - a fact that could only be denied through the most radical moral insensitivity. But it would be perverse to characterize what Douglass is doing as exhibiting marks and features and inviting his audience to infer that he is a member of the moral community, as if there were some gap between what he is doing at the podium and what constitutes membership in the moral community. Douglass is, rather, declaring himself a member of the moral community. Douglass is, at the podium, exercising his membership in such a way as to bring his audience to see what he is doing as such an exercise. To stand before Douglass in this way is to already concede his membership in the moral community. Douglass short-circuits the question of his standing by seizing the podium - to question whether Douglass has the standing to do so amounts to a failure to recognize what Douglass is doing as the exercise of his membership in the moral community. What remains is to bring his audience to see that what he is doing is such an exercise-it is not a matter of justifying such an exercise by appeal to something beyond the exercise itself. In declaration, Douglass thus takes a stance of insistence on his membership in the moral community, rather than one of inquiry.

One might still ask, at this stage, whether Douglass is in fact refusing to be reasonable when he declares his membership in the moral community. After all, the claim that Black people are members of the moral community is a (decisive!) reason to abolish slavery and other institutions of white supremacy.

But what is at issue in antebellum political discourse, Douglass thinks, is the claim that Black people are members of the moral community. According to Douglass (as noted above), not only slavery but also the enslaved are on trial before the court of public opinion. And slavery's advocate alleges that Black people are not members of the moral community because they lack the marks and features requisite for such membership. According to the view on the role of reasonableness in emancipatory politics which Douglass targets, when faced with a challenge to his membership in the moral community, Douglass ought to "argue and persuade more" with his "logic, reason, and words," because, if he does so, he is likely to sway public opinion in his favor. But Douglass, for the reasons presented above, thinks that such a political strategy will not achieve its desired aims. Instead, in the face of denials of his membership in the moral community grounded in justificatory appeals to requisite marks and features, Douglass declares his membership without seeking to reasonably address the arguments the white supremacist advances in opposition. The central characteristic of declaration here is that it advances a stance while refusing to engage in a further procedure of justification - through declaration Douglass marks where he will reason with slavery's advocate no further. This re- 
fusal, in turn, asks of his audience to understand why Douglass will reason with slavery's advocate no further: this is because there is no further fact which justifies Douglass's membership in the moral community, which he would have to evince in order to continue to reason with his interlocutor. In recognizing that there is no such further fact, Douglass's audience comes to recognize him as a member of the moral community-to take Douglass's declaration as such is thus to take him as a member of the moral community.

It is worth noting that Douglass's audience in the Fifth of July speech is generally composed of supporters of the antislavery cause. We can thus take Douglass as modeling for his audience what he thinks is a more effective discursive strategy for antislavery organizations. This strategy, moreover, plainly has implications for the structure of antislavery organizations. Douglass seizes the podium for himself; no white abolitionist can do this for him. A declaratory discursive strategy against white supremacy, then, depends centrally on capacities which only Black political actors can exercise - white political actors cannot enact the membership of Black political actors in the moral community for them. Insofar as Douglass's audience incorporates the declaratory model he puts on offer, then, their organizations will be fundamentally structured around Black political agents and thus Black political agency.

Douglass thus sees commonsense moral truths articulated by declarations as the ground for the discursive arm of a viable antislavery politics, because it offers an alternative to reasonable political deliberation on the fundamental matter of membership in moral community. In declaring his membership, and that of Black people, in the moral community, Douglass signals a refusal to subject the boundaries of moral community to the norm of reasonableness, motivating this refusal by pointing to the way in which the justifications for claims that he is excluded from moral community in fact presuppose his membership in the community. This suggests that the shape of the problem is a matter of recovery of commonsense moral truth, rather than discovery of moral truths in need of determination by inquiry. Where the latter is epitomized in Taney's question, "Whether the class of persons described in the plea in abatement compose a portion of this people, and are constituent members of this sovereignty?" the former is epitomized in Douglass's declaration, "The manhood of the slave is conceded."

\section{B. Delany's Objection}

Douglass's discursive strategy depends on a notion of moral common sense accessible through moral clarity, rather than deliberative inquiry. The resolution of certain questions, such as the boundaries of moral community, is a matter of leading others to a recovery of an insurgent common 
sense - that is, of coming to see plain moral truths aright. Delany, at times, seems to share Douglass's endorsement of antislavery politics grounded in common sense. In leveling his criticism of McLean's jury instructions in Giltner v. Gorham, ${ }^{73}$ Delany appeals to what "moral philosophy teaches, as common sense dictates," for "in the position assumed by Judge McLean, common sense is set at naught, and philosophy at defiance." ${ }^{74}$ The wrongness of McLean's jury instructions is clear, according to Delany, from commonsense reflection on plain moral truths. And, Delany thinks, McLean arrives at his morally noxious conclusion because he holds that plain moral truths cannot impinge on the procedures of legal deliberation: "[McLean] did not once express his abhorrence of slavery, but modestly evaded commitment on that point, by simply saying, 'Whatever may be our feelings,' and so forth, 'the law' is thus and so." ${ }^{\prime 5}$ Moreover, in his discussion of a natural claim to citizenship in Condition, Delany seems to have the makings of a declaratory strategy similar to the one Douglass models in his Fifth of July speech: as noted above, he describes such claims as "invulnerable to annulment," which suggests that such claims cannot be overturned through deliberative inquiry.

But, for Delany, the lesson drawn from the critique of reasonableness is not that antislavery needs an alternative discursive strategy for shortcircuiting the norm of reasonableness. Rather, the lesson is that the most viable antislavery strategy is emigration: Black people should leave the United States and form their own polity elsewhere. ${ }^{76}$ This lesson implies that a viable antislavery politics must, Delany thinks, ultimately withdraw from the sphere of antebellum US political discourse.

While Delany does not offer an explicit rejection of Douglass's alternative discursive strategy, we can piece together a criticism of Douglass's strategy from Delany's antebellum writings. Appeals to moral common sense cannot short-circuit the norm of reasonableness in antebellum political discourse because the norm of reasonableness constrains the shape of intelligible political discourse. Douglass's declaration thus cannot be heard by his audience but as a claim responsible to the norm of reasonableness. For Delany, this constraint on antebellum political discourse

73. Giltner, a slave catcher, filed suit against Gorham and six other defendants after a crowd in Marshall, Michigan, prevented Giltner from arresting the Crosswhite family, who had previously escaped from slavery in Kentucky. Members of the town also subsequently helped the Crosswhites escape to Canada. The jury found in favor of Giltner and awarded him substantial damages. According to Delany's remarks in his July 14 letter to Douglass, McLean appears to have instructed the jury not to allow any opinions about the moral status of slavery to inform their deliberations in the case.

74. Martin Delany, "Letter to Douglass, July 14, 1848," in Martin R. Delany: A Documentary Reader, ed. Robert S. Levine (Chapel Hill: University of North Carolina Press, 2003), 109-16, 114.

75. Ibid., 113.

76. Delany, Condition, 158-59. 
emerges most clearly in legal decisions such as Giltner v. Gorham. While what is wrong with McLean's decision in this case is just that he refuses to address moral considerations external to the law, this same fact renders antebellum political discourse impervious to Douglass's attempt at commonsense intervention.

We can bring Delany's worry into view by considering a presupposition built into Douglass's declarative strategy for establishing his standing in antebellum political discourse. In seizing the podium, Douglass exercises the capacities of a member of the moral community in order to compel his audience to recognize him as a member. This strategy crucially assumes that exercise of the capacities relevant to membership in the moral community does not depend on recognition of an agent's standing to exercise those capacities, which itself turns on recognition of membership in the moral community.

But, in some contexts, the exercise of capacities does seem to depend on recognition of an agent's standing to exercise them. For example, in at least some legal contexts, one has the capacity to sue in virtue of having her standing to sue recognized by the relevant authority. ${ }^{77}$ This is a point especially salient in legal discourse at the time in which Douglass and Delany are writing. In Scott v. Sanford, Scott is deprived of the capacity to sue because he lacks the standing to do so. Scott lacks the standing to sue because the court determines that he is not a citizen of the United States. It would not have been intelligible to the court for Scott to maintain that he is a citizen of the United States because he has the capacity to sue. Scott's assertion that he is able to sue would be understood as a claim in need of justification by appeal to his standing to do so-insisting before the court that he has the capacity to sue when his standing is challenged would beg the question.

The Delany-inspired worry here is that the court of public opinion will understand whatever capacity Douglass invokes to establish his membership in the moral community as dependent on standing in this second way. If so, then Douglass's audience will think that Douglass has the capacity to make moral demands on members of the moral community only if he has the standing to make such demands. Because the capacities in question are those exercised by members of the moral community, whether one has the standing to exercise them depends on whether one is a member of the moral community. But then it will appear to Douglass's audience that he claims to be a member of the moral community because he is exercising capacities that only those who are members of the moral community are capable of exercising. His audience will then insist that he is begging the question.

77. Mark V. Tushnet, "New Law of Standing a Plea for Abandonment," Cornell Law Review 62 (1977): 663-700, 665. 
The crucial moment here is that in which Douglass's declaration that he is a member of the moral community becomes a claim, in need of justification, that he is a member. This transformation occurs because Douglass's audience understands the capacities which Douglass purports (in their eyes) to exercise in making his declaration as capacities that depend on standing in the way that the capacity to sue depends on having the standing to sue: if one lacks standing, one lacks the capacity. Because some do deny that Douglass is a member of the moral community, and thus deny that Douglass has the standing to make moral demands on its members, the court of public opinion must determine whether Douglass has the capacity to make such demands by assessing the justification for this denial of standing. For Douglass to insist that he is a member of the moral community, and thus has standing, because he has the capacity to make moral demands on members of the community is, in the eyes of the court, to beg the question. This amounts to a reinsertion of the norm of reasonableness at the crucial moment: the exercise of the capacity must be justified by an appeal to standing, and the appeal to standing must be justified by further considerations that establish one as a member of the moral community. The problems of corruption of blood and undermined standing seep back in because Douglass's audience can only understand what Douglass is doing in this way.

For Delany, antebellum legal discourse in particular seems impervious to appeals to plain moral common sense. Delany denounces "litigation for protection a sham, and all judicial proceedings a farce, that should immediately be abolished," since this imperviousness ensures that legal "combat between Liberty and Slavery in this country must always terminate in favor of the latter." 78

One might respond on Douglass's behalf that, while Delany's argument might call for pessimism in the sphere of legal deliberation, this does not entail that Douglass's strategy is compromised in the wider sphere of political deliberation - the "court of public opinion" to which Douglass refers is merely a metaphor.

But Delany would insist that the metaphor of the "court of public opinion" points precisely to the way in which the shape of antebellum political deliberation recapitulates the assumptions of antebellum legal deliberation: "There are no people who ever lived, love [sic] their country and obey their laws as the Americans. Their country is their Heaventheir Laws their Scriptures - and the decrees of their magistrates obeyed as the fiat of God." ${ }^{79}$ Delany's observation is driven by remarks like Mc-

78. Delany, "Letter to Douglass, July 14, 1848," 113-15.

79. Delany, Condition, 155. Douglass makes a similar observation in his Fifth of July speech, decrying church leaders who "deliberately taught us, against the example of the Hebrews, and against the remonstrance of the Apostles, that we ought to obey man's law before the law 
Lean's in Giltner v. Gorham that "in the law is found the only safe rule by which controversies between man and man can be decided." ${ }^{80}$ But if antebellum legal deliberation transforms declarations of moral common sense into claims in need of justification, then we should expect that a culture of political deliberation fundamentally informed by the shape of legal deliberation will also engage in such alchemy. If so, then attempts at the recovery of moral common sense by appeal to moral clarity will not be intelligible as such to most participants in antebellum political discourse. The environment of antebellum political discourse is inhospitable, on Delany's view, to the recovery of moral common sense.

\section{CONCLUSION}

In this article, I have shown why Douglass and Delany think that the norm of reasonableness can actively undermine the aims of emancipatory politics, through the fixing of deliberative outcomes and the undermining of standing. I have shown that Douglass and Delany draw different conclusions for the viability of alternative discursive strategies for emancipatory politics, which turn on their differing perspectives on the legibility of appeals to moral clarity and common sense in antebellum US legal and political discourse.

As the epigraphs to this article should suggest, I think that Douglass's and Delany's critique of reasonableness presents a problem of urgency for us. The norm of reasonableness exerts great influence in our political culture (as Obama's remarks illustrate), and we are confronted with attempts to narrow the boundaries of moral community that clothe themselves in appeals to this norm (as Flynn's tweet reveals). But one might insist that white supremacy and chattel slavery in the antebellum United States is far too "special" and "distant" of a case from which to draw any conclusion about what the norm of reasonableness can or cannot do for emancipatory politics animating our own moment.

Even if we were to concede this point, one scholarly upshot of this article is that we can partially explain Douglass's and Delany's divergent strategies for emancipatory politics in the 1850s. As Gooding-Williams has observed, ever since Du Bois penned "Of Mr. Booker T. Washington and Others," ${ }^{81}$ the typology of assimilationism (Douglass) and separatism (Delany) has served as the dominant framework in the history of African

of God" (Douglass, "Meaning of July Fourth for the Negro," 201-2). Yet for Douglass, the aim here is to pressure church leaders to advance the moral clarity of antislavery and antiracism, since (here Douglass quotes Albert Barnes) "there is no power out of the church that could sustain slavery an hour, if it were not sustained in it" (201).

80. 4 McLean 402.

81. W. E. B. Du Bois, The Souls of Black Folk (Chicago: McClurg, 1903), chap. 3. 
American political thought. ${ }^{82}$ The dominance of this distinction can instill these categories with an aura which suggests that they are fundamental, as if one is first an assimilationist or a separatist, and that it is this commitment which informs the rest of one's antiracist politics.

The analysis of Douglass's and Delany's divergent responses to the critique of reasonableness above helps to puncture this aura and contributes to the "healthy skepticism" Gooding-Williams advocates in response to attempts to schematize the history of African American political thought. ${ }^{83}$ In their political thought, Douglass's and Delany's shared point of departure is the question, "What kind of politics should African Americans conduct to counter white supremacy?" 84 The degree to which their emancipatory politics approximate the Du Boisian ideal types of assimilationism and separatism follows from their assessments of the viability of particular political strategies. Douglass, for example, sees a strategy for pursuing emancipatory politics before the antebellum court of public opinion, while Delany denies that any such strategy is viable. ${ }^{85}$ Both see this domain of political discourse as one potential avenue for resistance, and both think that the norm of reasonableness which governs it presents a problem for resistance. But this then suggests that the point of emphasis should be on the assessments - for example, of the viability of pursuing antislavery politics in a sphere of discourse dominated by the norm of reasonableness - which will be just as dynamic as the political situation to which they correspond, rather than the static ideal types to which the assessments will correspond with varying degrees of "faithfulness."

Framing Douglass's and Delany's critique of reasonableness in this way, moreover, makes clear how to respond to our objector. The question of how to resist white supremacy is still an especially urgent question for us, deliberation before our own court of public opinion is still an especially salient avenue for us, and the norm of reasonableness still governs conduct in the court of public opinion. In the face of calls for dialogue with those who advocate fear of members of our moral community as "rational," it is

82. Gooding-Williams, In the Shadow of Du Bois, esp. 5-9.

83. Ibid., 7.

84. Ibid., 1.

85. The point here is not that the assimilationist stance is the default, and that one is a separatist insofar as one thinks that "assimilationist" strategies are not viable. This objection smuggles the categories back into the ground floor of the analysis. The point is that Douglass and Delany are both in the business of resisting white supremacy and slavery by whatever means they can make use of, and their assessments of the means that they can make use of differ.

86. Take the trajectory of Delany's political career: from antebellum separatist to major in the Union army to candidate for lieutenant governor in South Carolina to judge and back again to advocate for separatism. It is unclear why we should think that the categories of separatist and assimilationist render this trajectory particularly lucid. 
urgent for us to examine the extent to which the norm of reasonableness contributes productively to emancipatory political aims.

In this connection, the interpretation of Douglass's and Delany's antebellum political thought that I have provided here offers three central claims which should inform the emancipatory politics of our moment: ${ }^{87}$

1. Comporting oneself reasonably when engaging in political discourse with oppressive ideology can be counterproductive under conditions of substantial oppression. Reasonable engagement with oppressive ideology opens the way for proponents of such ideology to $(a)$ manipulate deliberative inquiry into the ideology's claims and $(b)$ undermine the standing of political actors targeted by the ideology.

2. To the extent that a viable emancipatory politics must engage in the political discourse of its community, we should consider strategies which short-circuit the problems posed by comporting oneself reasonably in the face of oppressive ideology. Douglass's (relative) optimism on the possibility of advancing antislavery in the United States is grounded, in part, in the alternative discursive strategy of declaration: the insistence on one's membership in a community, with the aim of bringing one's audience to recognize one's membership (as opposed to bringing one's audience to affirm justifications for one's membership).

3. One important constraint on the viability of alternative discursive strategies for an emancipatory politics is the extent to which such strategies will be intelligible to one's audience as alternatives to comporting oneself reasonably in the face of oppressive ideology. Delany's pessimism is grounded, in part, in the seeming inevitability that Douglass's audience will hear his declarations as claims in need of justification. Because reasonableness is a norm deeply engrained in our political culture, it is important to ask whether the norm is likely to distort a particular alternative discursive strategy that we may employ in advancing emancipatory political aims.

87. I do not mean to suggest that these three claims exhaustively characterize the interpretation above. 